\title{
HYDROLOGY-DRIVEN SEASONAL CHANGES IN THE PHYTOPLANKTON OF A SUBTROPICAL RIVER (RIACHO Formosa, ARgentina)
}

\author{
GABRIELA MATALONI ${ }^{1,2}$, LUCIANA BURDMAN ${ }^{1,2}$, VALERIA CASA ${ }^{1,2}$, DANIELA GONZALEZ ${ }^{1,2}$ \\ and MARÍA CLARA MASETTI ${ }^{1}$
}

\begin{abstract}
Summary: The Riacho Formosa is one of many autochtonous watercourses running along the subtropical region of the Wet Chaco Plains and draining into Paraguay River. Their typical hydrological cycle is characterized by a late winter low phase and a high phase throughout the warm season. As part of a baseline characterization, the composition and structure of the phytoplankton were studied in relation to river depth, water temperature, $\mathrm{pH}$, conductivity and transparency through 4 seasonal samplings between June 2015 and March 2016. A rich phytoplankton community (338 taxa) was revealed in this study. A few species of Cryptophyceae and Euglenophyceae dominated the community, especially during low waters. A cluster analysis showed that community compositions were more dissimilar over time than along the watercourse, and were spatially more homogeneous during high waters. A canonical correspondence analysis showed that environmental features significantly explained $42.6 \%$ of the total variance of species data $(p=0.004)$. We conclude that phytoplankton responds to hydrological changes through a high species turnover, with dominance peaks of euryhaline, shadow adapted and organic matter exploiting taxa during low waters.
\end{abstract}

Key words: Phytoplankton ecology, Formosa, subtropical rivers, hydrological seasonality.

Resumen: Cambios estacionales dependientes de la hidrología en el fitoplancton de un río subtropical (Riacho Formosa, Argentina). El Riacho Formosa es uno de los numerosos cursos de agua que surcan el Chaco Húmedo y desembocan en el río Paraguay. El ciclo hidrológico típico de estos ríos se caracteriza por un estiaje al final del invierno y una creciente durante la época cálida. En una caracterización de línea de base se estudiaron la composición y estructura del fitoplancton en relación con la profundidad, temperatura del agua, $\mathrm{pH}$, conductividad y transparencia mediante 4 muestreos estacionales, entre junio de 2015 y marzo de 2016. La comunidad del fitoplancton fue rica (338 taxa) y dominada por pocas especies de Cryptophyceae y Euglenophyceae, especialmente en aguas bajas. Un análisis de agrupamiento reveló una mayor variación temporal en la composición taxonómica que a lo largo del río, y una mayor homogeneidad espacial durante la fase de inundación. Según un análisis de correspondencia canónica, las variables ambientales explicaron el $42,6 \%$ de la varianza total $(p=0,004)$. Concluimos que el fitoplancton responde a los cambios hidrológicos a través de una alta tasa de recambio de especies, con dominancia de taxones eurihalinos, adaptados a la sombra y consumidores de materia orgánica durante el estiaje.

Palabras clave: Ecología del fitoplancton, Formosa, ríos subtropicales, estacionalidad hídrica.

${ }^{1}$ Laboratorio de Biodiversidad, Limnología y Biología de la Conservación - Instituto de Investigación e Ingeniería Ambiental - Universidad Nacional de San Martín

${ }^{2}$ Consejo Nacional de Investigaciones Científicas y Técnicas

Corresponding author: Mataloni, G. (gmataloni@unsam.edu.ar) 


\section{INTRODUCTION}

Among the limnological regions of Argentina defined by Tell et al. (2014), the Chaco-Pampa Plain is the most extense, and its northern area overlaps with the Warm climatic region, which reputedly hosts the richest phycoflora and accounts for a large number of probably endemic species (Tell, 2014). Within this area, the ecology of the phytoplankton inhabiting Paraná and Paraguay rivers and their floodplains has deserved much attention over the past 30 years, as comprehensively summarized by Devercelli et al. (2014) and Zalocar de Domitrovic et al. (2014a), while small local tributaries have been less studied, mostly through single point samplings (Zalocar de Domitrovic et al., 2014b). The phycological overall diversity of the area, in turn, was surveyed over many floristic papers, as detailed in Zalocar de Domitrovic \& Forastier (2008). Riacho Formosa -the local name of Formosa River-is a small tributary of the ParanáParaguay Corridor, contributing black waters from the Chaco-Pampa Plain to the lower Paraguay River (Minotti, 2016). Although its entering the Paraguay River floodplain, $700 \mathrm{~m}$ upstream from the drinking water intake for Formosa City, justifies a thorough ecological study of this river, only water quality in terms of physical, chemical and bacteriological features was surveyed around Formosa City (García \& Salinas, 2014).

This paper contributes to the baseline study of the Riacho Formosa through two objectives:

Characterizing the different reaches of the Riacho Formosa over a four-season period based on abiotic features and structural descriptors (taxonomic composition, species richness, diversity) of the phytoplankton community.

Analyzing the seasonal changes of the phytoplankton structure and their relation with the hydrology of the Riacho Formosa.

\section{Material and Methods}

\section{Study area}

The Riacho Formosa is a $50 \mathrm{~km}$-long lowland stream, whose watershed is located between the Pilagá River to the north, and San Hilario River and Pucú Stream to the south (Fig. 1). Most of its catchment belongs to the Alluvial Fans unit of the
Paraná-Paraguay Corridor (Minotti et al., 2013). Its headwaters are located in a network of tropical swamps (sensu Carter \& Beadle, 1930) where the alluvial fans of the Bermejo and Pilcomayo rivers meet. The main river starts where a series of paleovalleys coalesce into a single valley, its narrow central channel having small meanders and low levees. In the middle reaches, the river deepens its course and presents irregular meanders, which widen, get more numerous and complex covering the whole paleovalley, as it reaches the Paraguay floodplain (Cucchi, 1973). Natural levees are covered by gallery forest on the inner and steep side and palm trees (Copernicia alba Morong) on the outer gentle slopes, while backwaters and old meanders present stands of emergent macrophytes (Cyperus giganteus Vahl, Thalia geniculata Linneo, Typha domingensis Persoon) and open water. Its water regime depends mostly on local precipitation and surface flow, which take place during the austral warm season (November through April). The dry season is in late winter, when the base flow is provided by the local watertable (mostly hyporheic flow) and regional groundwater inputs. The lower reaches of the Riacho Formosa are also affected by Paraguay River floods, which take place during the austral winter due to the Pantanal retardation effect. Extraordinary floods take place during El Niño years, when the waters of the Paraguay River can enter an already high Riacho Formosa during summer.

\section{Sampling and analysis}

Six sampling sites were located within the Riacho Formosa main watershed: E1 and E2 in two paleovalleys of the headwaters, R1 and R3 in the middle stretch, and R4 and R5 in the lower reaches, within the Paraguay River floodplain. Four seasonal samplings were carried out between June 2015 (late autumn) and March 2016 (late summer). At each sampling station water temperature, $\mathrm{pH}$, dissolved oxygen and conductivity were measured with a portable multiparametric Hach SensION probe at $20 \mathrm{~cm}$ depth, water transparency was estimated with a Secchi disk, and depth was measured with portable sonars (Hawk Eye or Fish Finder, 0.1m precision) or $1 \mathrm{~m}$ graduated scale $(\mathrm{mm})$, depending on water height. Data on local Paraguay River water level and precipitation at Formosa city were provided by the Subsecretaría de Recursos Naturales y Ambiente of Formosa Province. 


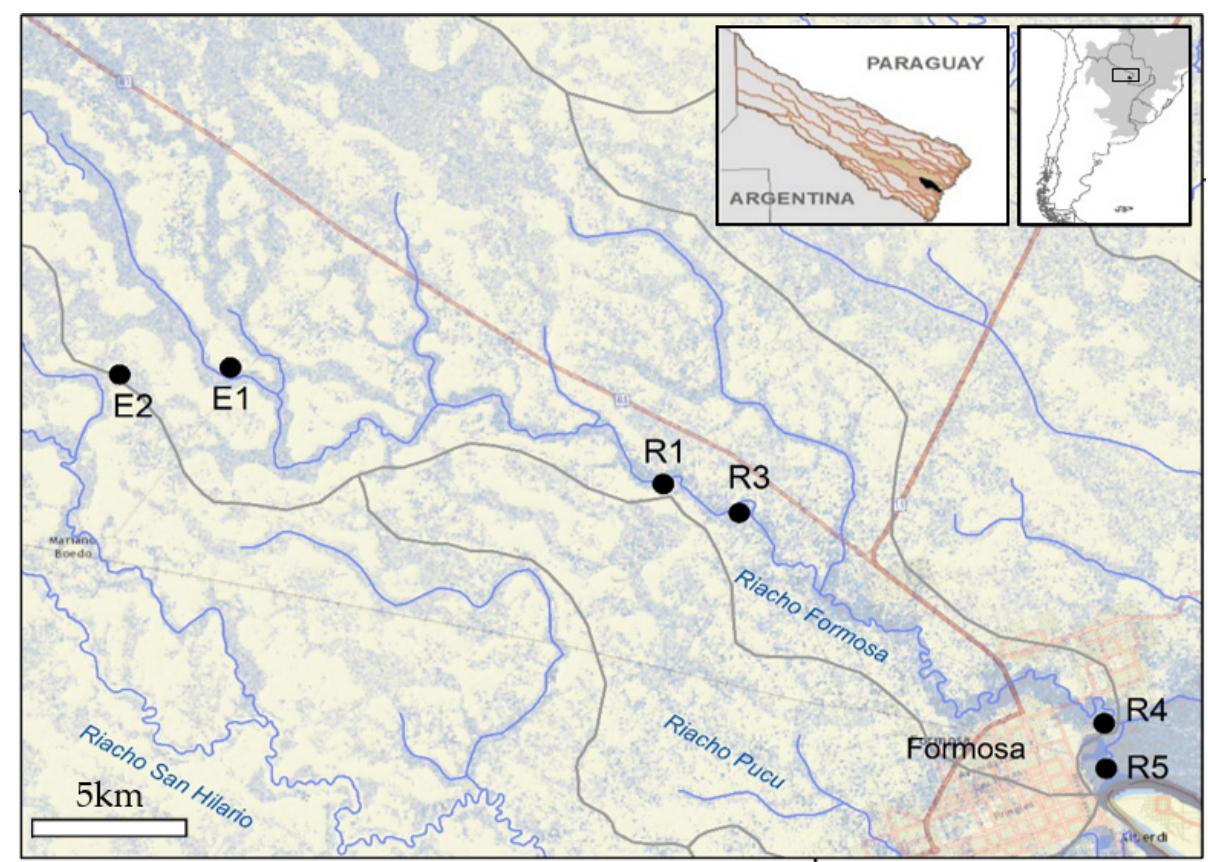

Fig. 1. Map of the Riacho Formosa, showing the location of the sampling points.

Qualitative samples of the nano- and microsized fraction of the phytoplankton were collected by repeatedly towing a $15 \mu \mathrm{m}$ pore size plankton net when possible. In low waters, samples were taken by scooping a bucket and then filtering the contents through the same net. All samples were fixed with $1 \%$ formaline. Two replicate samples for the quantitative analyses of taxonomic groups were collected using $100-\mathrm{mL}$ plastic flasks and preserved with $2 \%$ acetic Lugol's solution. At the laboratory, distinct morphotypes were photographed using an Olympus BX-41 microscope. Taxonomic identifications were made to the lowest possible level with the aid of a vast amount of literature on general taxonomy and local phycoflora. Replicate $10-\mathrm{mL}$ plankton chambers were left to sediment for at least 24 $\mathrm{h}$ and counts performed in an inverted microscope at x400 magnification according to Utermöhl (Utermöhl, 1958). Abundances of the major taxonomic groups were calculated accepting a maximum counting error of $20 \%$ for the dominant taxonomic groups (Venrick, 1978).

The abiotic features of the Riacho Formosa were summarized by means of a Principal Component Analysis (PCA) using CANOCO 4.5 software
(terBraak \& Smilauer, 1998). Samples were grouped based on their floristic composition by means of a cluster analysis using Jaccard's distance and weighted average linkage. Shannon's diversity index (Magurran, 2004) was calculated at the taxonomic group level with Infostat Software. In order to assess the influence of abiotic factors on the abundance and composition of the different main taxonomic groups of the phytoplankton, a canonical correspondence analysis (CCA) was performed using CANOCO 4.5 software (ter Braak \& Smilauer, 1998). No data transformations were needed to perform this analysis. A forward selection of the variables selected conductivity, Secchi depth, total depth and temperature as the most influential variables for sample ordination.

\section{Results}

\section{The Riacho Formosa}

Depth of the Riacho Formosa varied along its course, with all sampling points located in the sources and middle stretch showing much lower depths than those located on the alluvial plain of the Paraguay River (R4, R5). Depths at these points were very 
similar to the ones simultaneously recorded at the Formosa Port (Fig. 2). During the drought period (precipitation: $55 \mathrm{~mm}$ over the previous month to the September sampling) the river lowered its depth. This influence was stronger on the catchment of the Riacho Formosa than on the sampling points located on the alluvial plain of Paraguay River. Heavy rains over the El Niño 2015-2016 summer resulted in an unusual early autumn flood of Paraguay River, whose level surpassed the limit for evacuation of the area. The waters of Riacho Formosa were less transparent, more ion-rich during the dry period, particularly at the middle reach. Mean water temperature of the river varied little, between $22.3^{\circ} \mathrm{C}$ in September and $27.4^{\circ} \mathrm{C}$ in March (Table 1). According to the PCA based on abiotic features, the first axis alone explained 56.35\% of the total variability, and expressed a temporal rather than spatial pattern, with all late winter (September) samples located to the left side of the diagram (Fig. $3)$. Although all variables were influential on this ordination (lowest eigenv. 0.627), transparency was of outmost importance (eigenv. 0.908). The second axis, in turn, explained $19.2 \%$ of the recorded variability, mainly due to the influence of temperature (eigenv. 0.593) and depth (eigenv. 0.487).

\section{The phytoplankton}

A total number of 338 taxa was recorded, with individual samples hosting between 16 and 84 taxa. The richest group was Conjugatophyceae, entirely composed of desmids, with 36 taxa in a single sample (E1 March), followed by Euglenophyceae (27), Bacillariophyta (24) and Chlorophyta (21). While paleovalleys (E1 and E2) showed minimum values for species richness (S) in June, the medium reach (R1-R3) was poorest during the September drought. Species richness was highest during December at all sites but R5, near the mouth of Riacho Formosa, which showed a strong peak for this parameter in March (Fig. 4).

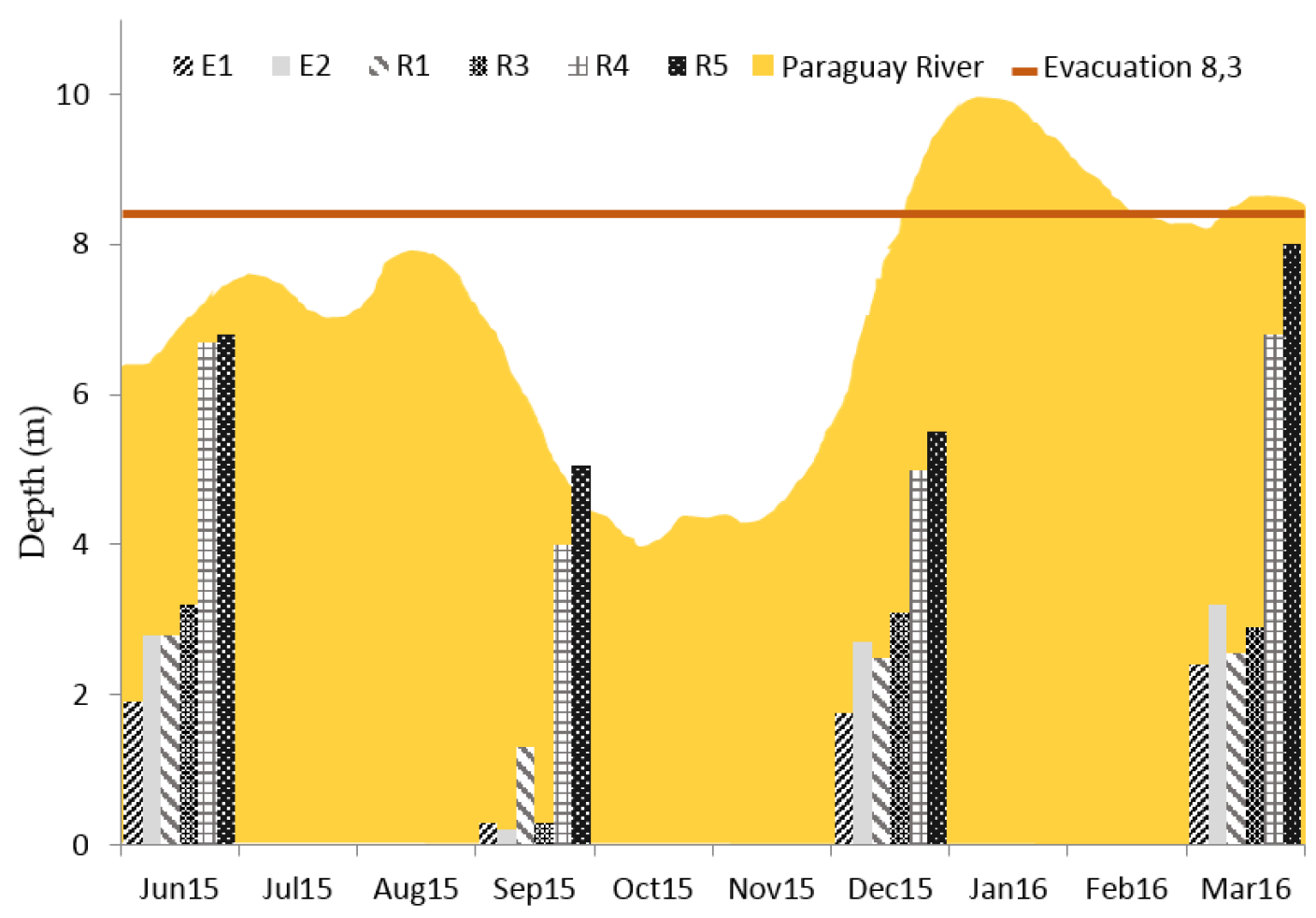

Fig. 2. Depth of Formosa River at each sampling station and date (columns) and depth of Paraguay River over the study period (background). E1 - R5: sampling stations. Jun 15, Sep15, Dec15, Mar16: sampling dates. Horizontal line: Evacuation limit for Paraguay River depth. 
Table 1. Values of water temperature (WT), pH, conductivity (Cond), Secchi disk depth (Secchi) and river depth (Depth) at each sampling station over the study period and average values for Riacho Formosa for each season. E1 - R5: sampling stations.

\begin{tabular}{|c|c|c|c|c|c|c|c|c|}
\hline & & E1 & E2 & R1 & R3 & R4 & R5 & \\
\hline & Latitude & $26^{\circ} 3^{\prime} 26,62$ "S & $26^{\circ} 6^{\prime} 12,81^{\prime \prime S}$ & $26^{\circ} 5^{\prime} 55,25^{\prime \prime} \mathrm{S}$ & $26^{\circ} 5^{\prime} 48,21^{\prime \prime S}$ & $26^{\circ} 9^{\prime} 48,67^{\prime \prime} S$ & $26^{\circ} 10^{\prime} 28,46$ "S & Average \\
\hline & Longitude & $58^{\circ} 25^{\prime} 46,19^{\prime \prime} \mathrm{W}$ & $58^{\circ} 28^{\prime} 28,33^{\prime \prime} \mathrm{W}$ & $58^{\circ} 16^{\prime} 47,15^{\prime \prime} \mathrm{W}$ & $58^{\circ} 16^{\prime} 28,65^{\prime \prime} \mathrm{W}$ & $58^{\circ} 9^{\prime} 10,43^{\prime \prime} \mathrm{W}$ & ( $58^{\circ}$ 9' 19,32"W & \\
\hline & June & 24.7 & 25.2 & 24.2 & 25.4 & 23.5 & 23.8 & 24.5 \\
\hline రิ & September & 20.3 & 19.8 & 23.2 & 24.9 & 23.0 & 22.7 & 22.3 \\
\hline 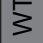 & December & 20.2 & 19.0 & 26.6 & 26.4 & 28.7 & 26.4 & 24.6 \\
\hline & March & 28.4 & 29.9 & 25.6 & 26.3 & 26.6 & 27.4 & 27.4 \\
\hline & June & 6.33 & 6.57 & 6.43 & 6.58 & 6.28 & 6.23 & 6.40 \\
\hline & September & 6.70 & 6.70 & 6.86 & 6.80 & 6.38 & 6.65 & 6.68 \\
\hline & December & 6.21 & 7.53 & 6.46 & 6.24 & 6.20 & 4.99 & 6.27 \\
\hline & March & 6.16 & 6.63 & 6.15 & 6.45 & 6.25 & 6.66 & 6.38 \\
\hline 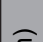 & June & 86.0 & 83.8 & 73.1 & 72.4 & 89.3 & 87.5 & 82.0 \\
\hline$\frac{0}{0}$ & September & 108.7 & 124.7 & 402.0 & 394.3 & 258.3 & 142.6 & 238.4 \\
\hline 응 & December & 60.9 & 90.7 & 67.8 & 67.3 & 96.2 & 111.1 & 82.4 \\
\hline & March & 47.9 & 58.9 & 49.8 & 51.3 & 66.3 & 89.0 & 60.5 \\
\hline & June & 40.0 & 45.0 & 26.0 & 27.5 & 40.0 & 30.0 & 34.8 \\
\hline है & September & 12.5 & 3.0 & 5.0 & 3.0 & 15.0 & 22.5 & 10.2 \\
\hline$\overline{0}$ & December & 53.5 & 43.0 & 50.0 & 68.0 & 58.0 & 60.0 & 55.4 \\
\hline & March & 70.0 & 63.0 & 60.0 & 33.0 & 33.0 & 65.0 & 54.0 \\
\hline & June & 1.90 & 2.80 & 2.80 & 3.20 & 6.70 & 6.80 & 4.03 \\
\hline$\widehat{\xi}$ & September & 0.30 & 0.20 & 1.30 & 0.30 & 4.00 & 5.05 & 1.86 \\
\hline 임 & December & 1.75 & 2.70 & 2.50 & 3.10 & 5.00 & 5.50 & 3.43 \\
\hline & March & 2.40 & 3.20 & 2.55 & 2.90 & 6.80 & 8.00 & 4.31 \\
\hline
\end{tabular}

The clustering of samples based on floristic composition (Fig. 5) followed a temporal pattern. Samples representing the whole river during the warm, high water period (Dec-Mar) clustered together, later joined by a smaller group comprising late autumn (June) samples, and finally by another cluster composed mainly by the dry winter (September) samples. Although no clear spatial pattern was observed regarding the taxonomic composition of samples, the difference between the total number of species recorded over the whole period for the entire system (338) and each sampling site (113 - 165 spp) shows a high species turnover along the course of the Riacho Formosa.

Phytoplankton total abundances were generally low (124-1218 ind $/ \mathrm{ml}$ ) and did not show a clear trend either temporally or spatially. Instead, abundances of major taxonomic groups had distinct variation patterns over the study period at the different sites (Fig. 6). Nevertheless, a general trend towards dominance by flagellated Cryptophyta and Euglenophyta all along the river was observed during the winter drought. Consequently, during this season, phytoplankton diversity $(\mathrm{H})$ as per major taxonomic groups showed 
Bol. Soc. Argent. Bot. 53 (2) 2018

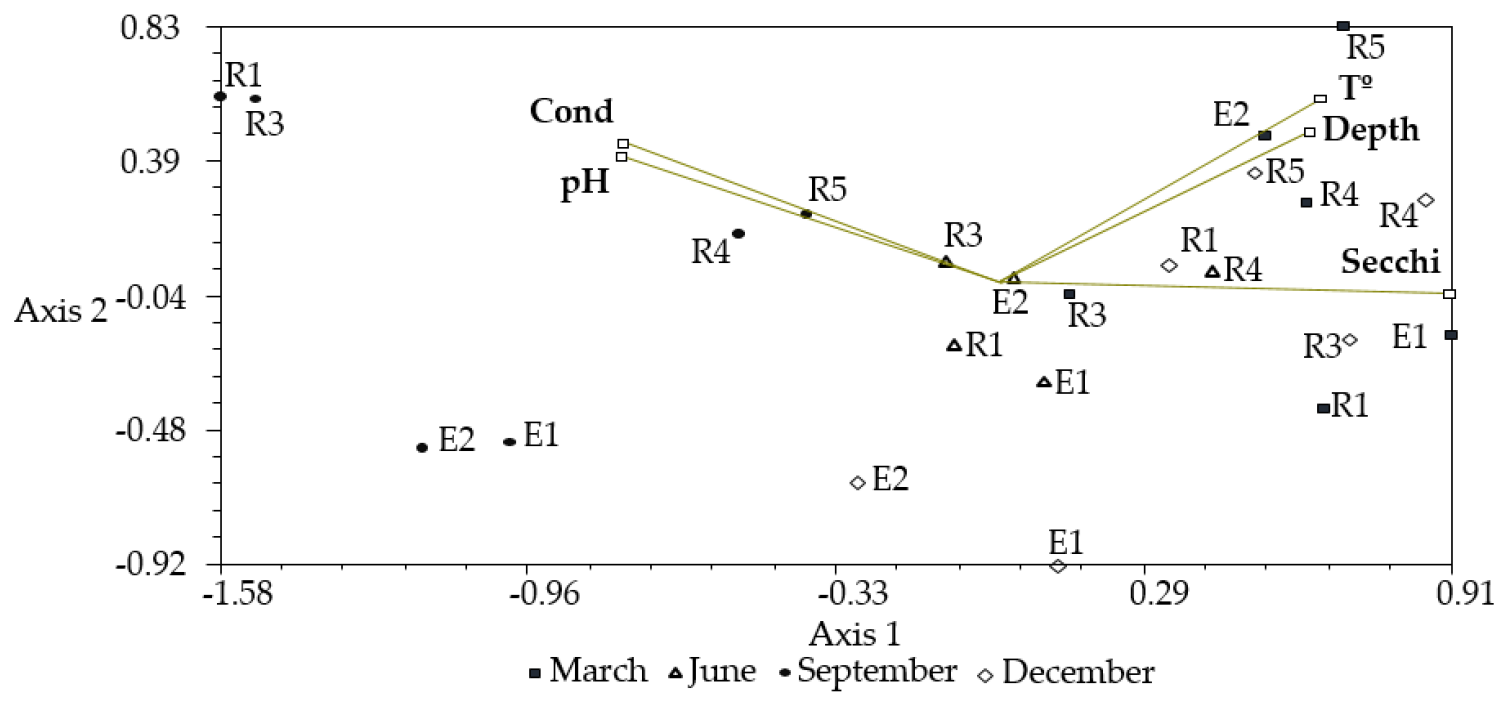

Fig. 3. Plotting of samples according to the results of the Principal Components Analysis. Cond: conductivity, $\mathrm{T}^{\circ}$ : water temperature, Depth: depth of Formosa River, Secchi: depth of the Secchi disk. White triangles: June 2015, black circles: September 2015, white diamonds: December 2015, black squares: March 2016.

Jun15

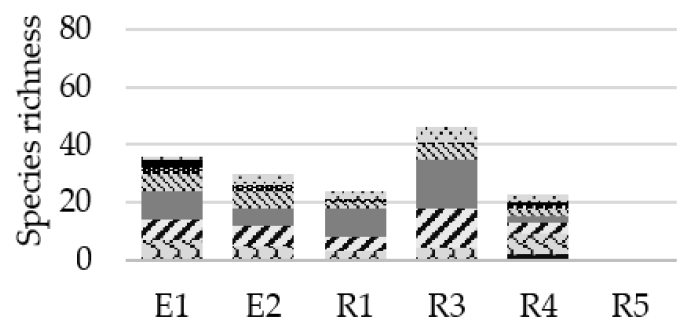

Dec15

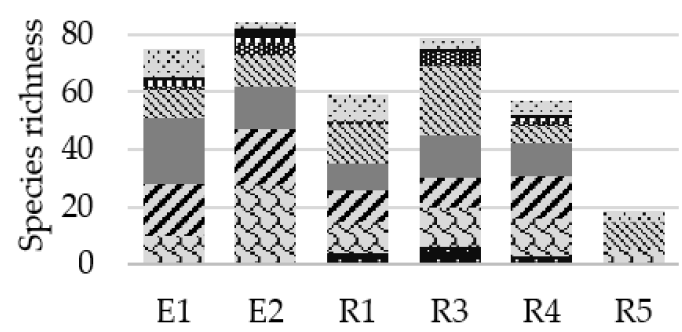

Sep15

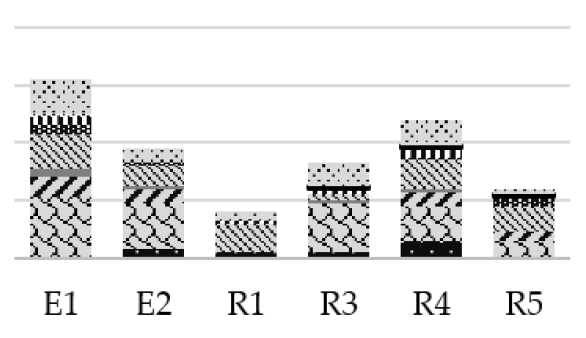

Mar16

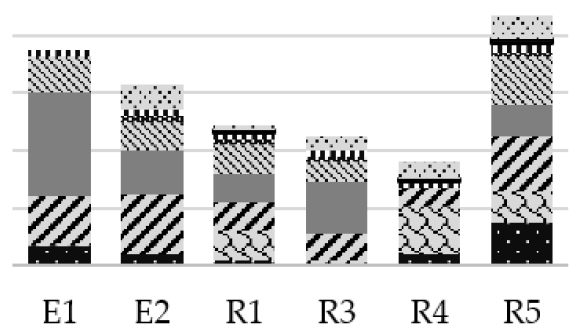

Cyanobacteria Kuglenophyceae $\mathbb{Z}$ Chlorophyta $\square$ Conjugatophyceae $\mathbb{N}$ Bacillariophyta w Chrysophyceae IIII|Cryptophyta Dinophyceae Phaeophyceae Incertae sedis

Fig. 4. Species richness for each major taxonomic group at each sampling point over the study period. E1 - R5: sampling stations. 


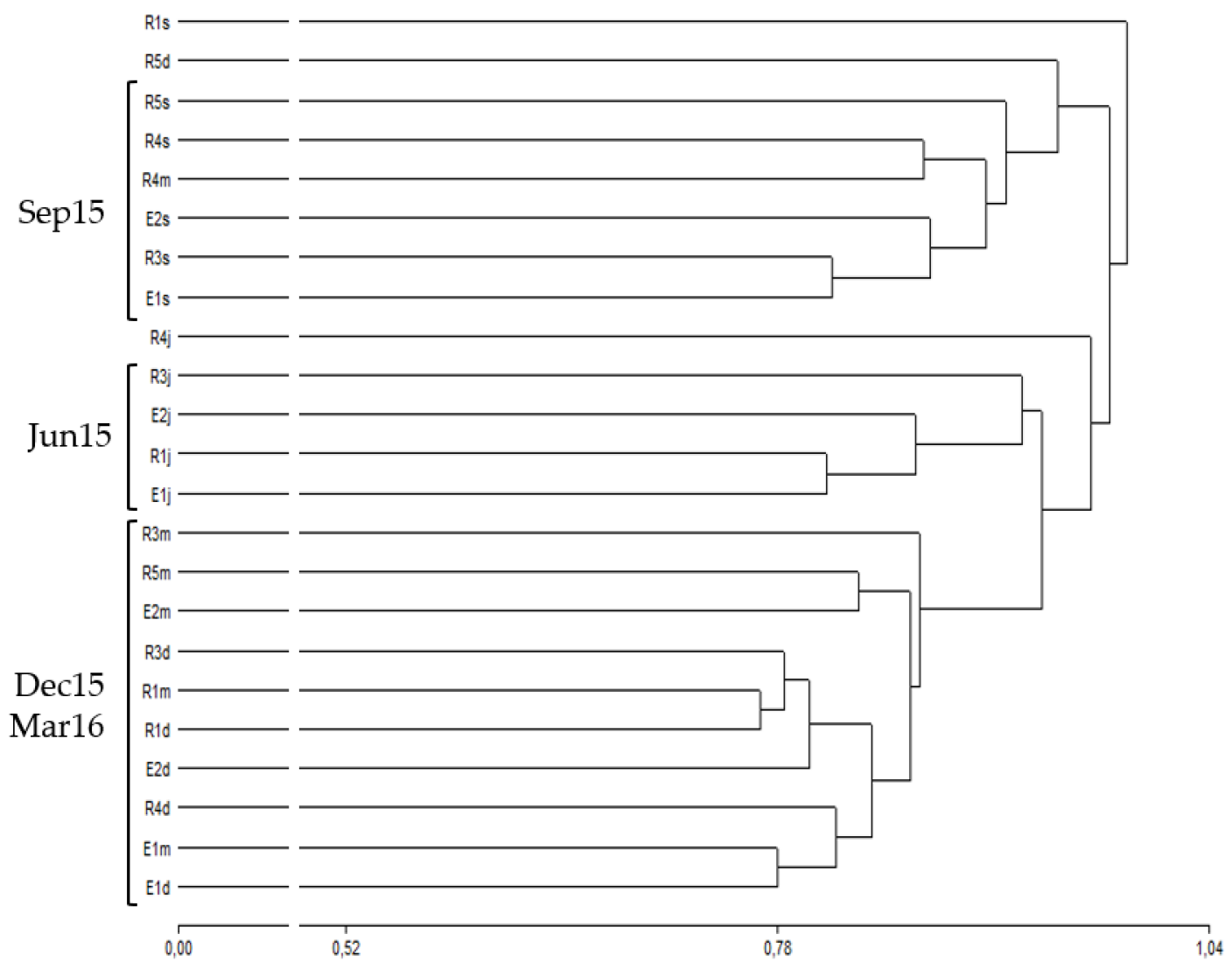

Fig. 5. Clustering of samples based on the taxonomic composition of the phytoplankton. Combinations of letters and numbers show a given sampling event at a given site, e.g. R1s: September sampling at R1 station. Clusters of samples mostly belonging to a given sampling date are shown. Arrows show the directions of the environmental gradients reflected.

its lowest values in all stations except R1 (range 0.951.64). Maximum values for this parameter (range 1.66-1.81), in turn, were recorded in December.

According to the results of the canonical correspondence analysis (CCA), four variables exerted a significant influence on the ordination of sampling sites and taxonomic groups (Fig. 7). The first two canonical axes explained $42.6 \%$ of the total variance of species data, and accounted for $97.1 \%$ of the species-environment relation. The first canonical axis $(p=0.012)$ and the sum of all canonical axes $(p=0.004)$ were significant, as confirmed by a MonteCarlo test with 499 permutations. The first axis ordinated samples along a drought gradient, with September samples located on the right side of the diagram and characterized by high abundances of Cryptophyceae and Euglenophyceae. Second canonical axis, in turn, ordinated samples along a spatial gradient, with paleovalleys samples (E1, E2) located in the lower section of the diagram and relating to higher water transparency and abundances of Conjugatophyceae. In turn, sampling sites in the Paraguay River alluvial plain (R4, R5) were located in the upper left quadrant, and reflected the increasing depth of the river and high summer abundances of Cyanobacteria.

Regarding abundances of the taxonomic major groups, Cryptophyceae dominated the phytoplankton in June and September along the high and midreaches of the river despite their low species richness, and were mainly represented by Rhodomonas minuta Skuja and a few species belonging to the genera Cryptomonas Ehrenberg, and Chroomonas Hansgirg. While Euglenophyceae were the second dominant 
Bol. Soc. Argent. Bot. 53 (2) 2018

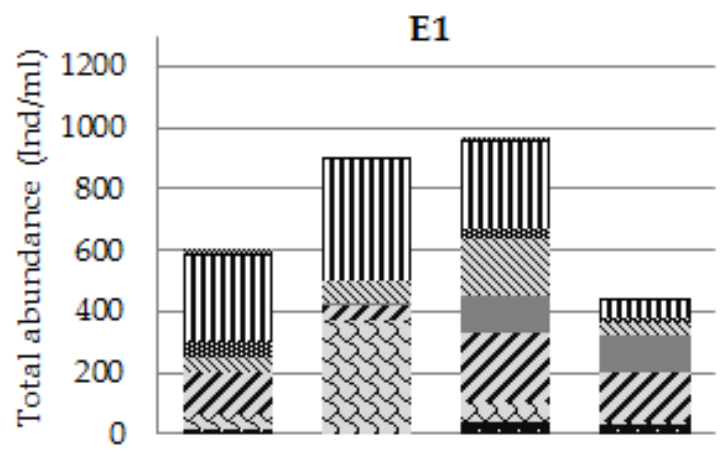

E2

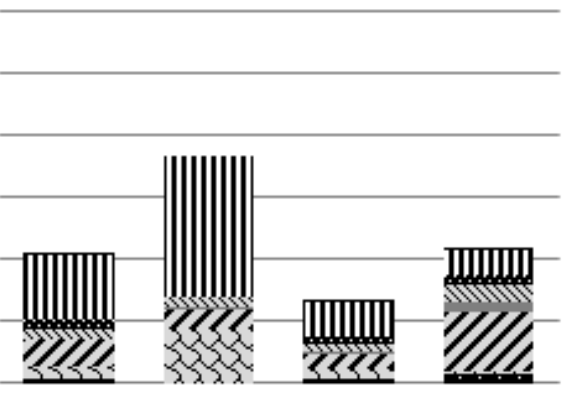

R1

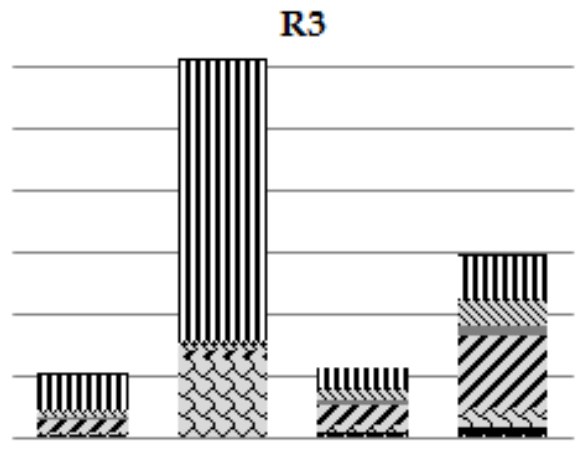

R4

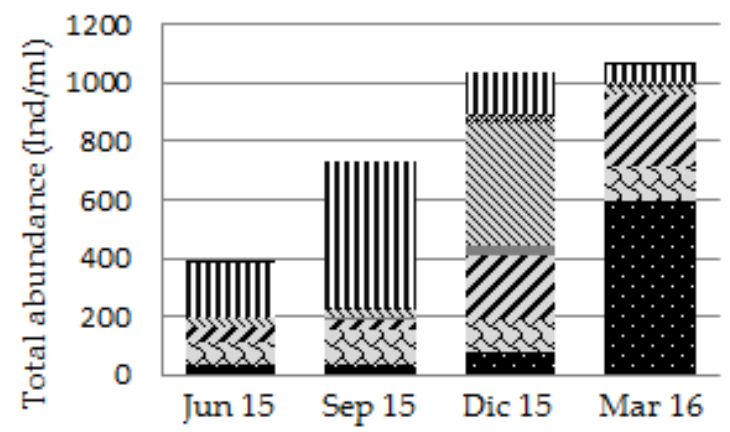

R5

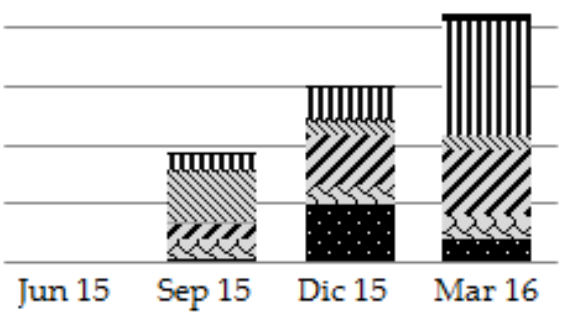

$\because$ Cyanobacteria Xèglenophyceae

Ind Chrysophyceae I||l|Cryptophyta
V.Chlorophyta

Dinophyceae
Conjugatophyceae $\$$ Bacillariophyta

Phaeophyceae
Incertae sedis

Fig. 6. Abundances for each major taxonomic group at each sampling point over the study period. E1 - R5: sampling stations. Jun 15, Sep15, Dec15, Mar16: sampling dates.

group along this section of the river during the September drought, they instead showed a high species richness, mostly on account of the genera Trachelomonas Ehrenberg (with 25 species) and Lepocinclis Perty. Opposedly, Conjugatophyceae (desmids) displayed the lowest number of taxa during this period, and their abundances were low throughout the study. Most representative genera within this group were Staurodesmus Teiling (with 13 taxa), Closterium Nitzsch ex Ralfs, and Staurastrum Meyen ex Ralfs. In turn, half of the thin Leptolyngbya-like Oscillatoriales filaments contributing to the richness peak observed in R5 in the latest sampling event were new to the studied flora. 


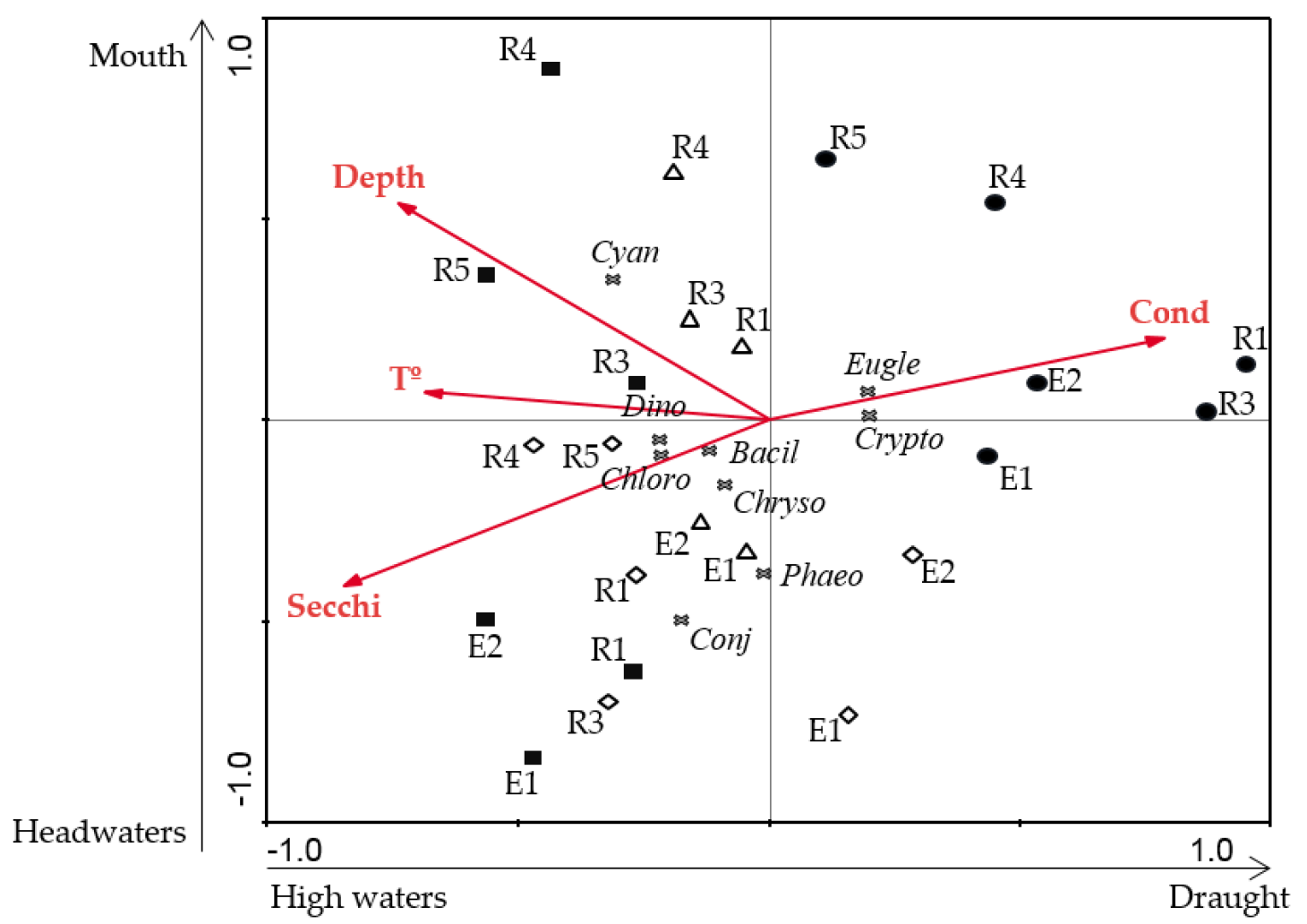

Fig. 7. Ordination of samples according to the values of environmental variables and abundances of major taxonomic groups. Bacil: Bacillariophyta, Cyan: Cyanobacteria, Chloro: Chlorophyta, Crypto: Cryptophyta, Eugle: Euglenophyceae, Phaeo: Phaeophyceae, Conj: Conjugatophyceae, Chryso: Chrysophyceae, Dino: Dinophyceae. Abbreviations of environmental variables and symbols for sampling dates as in Fig. 3.

\section{Discussion}

Despite flowing through the capital city of Formosa Province, Formosa River has deserved little attention to present. Yet, its location between the watersheds of Pilagá River to the north and San Hilario river to the south provides an interesting source for comparison, as these waterbodies show similar low conductivity values (less than $500 \mu \mathrm{S} /$ $\mathrm{cm}$ during low waters in rainy years) as compared to other autochtonous streams located in surrounding catchments and, like the Riacho Formosa, are not covered by aquatic macrophytes (Zalocar de Domitrovic et al. 2014b). Among the environmental parameters studied, river depth, transparency and conductivity accurately reflected the hydrological cycles that drive the structure, abundance and composition of the phytoplankton, as described by Zalocar de Domitrovic et al. (1986, 2014b) for other local watercourses in this region. In general, the high water period gives rise to a higher species richness, as the fluvial overflow allows contact with lenitic waterbodies and other streams, thus favouring the exchange of propagules with different survival strategies, as proposed by Zalocar de Domitrovic et al.(2014b). Hydrology, in turn, interacts with spatial variation, resulting in physical and chemical features of the headwaters (E1, E2), medium reach (R1, R3) and mouth (R4, R5) responding differently to hydric balance. In particular, the medium reach showed the highest variation in conductivity during low waters, as observed by García \& Salinas (2014). This interaction would account for the high species turnover both in space and time of the phytoplankton, which is expected to be more pronounced during dry years. 
Headwaters hosted a large number of chlorophytes and desmids, especially under high waters and high transparency conditions. The latter group stands for the functional group N (Reynolds et al., 2002), which is particularly sensitive to stratification. The middle reach showed the most pronounced rise in turbidity and conductivity during the winter drought, and was characterized by a stronger dominance of flagellated Cryptophyceae and Euglenophyceae during this period. The former flagellates (functional group Y sensu Reynolds et al., 2002) are tolerant to low light conditions, while euglenoids $\left(\mathrm{W}_{1}, \mathrm{~W}_{2}\right)$ thrive in low waters, when stagnation and decomposing organic matter provide a rich substratum. Interestingly, Zalocar de Domitrovic et al. (1982, 1986) also found Cryptophyceae to numerically dominate a number of local rivers despite low species richness in Formosa and Chaco plains. Our two last sampling sites, located within the Paraguay floodplain, revealed a strong environmental discontinuity, as the waters partially mix in a system of interconnected ponds and abandoned meanders that regulate the fluctuations of this large river. This fact is reflected by their distinct floristic composition. In particular, the species list of R5 during the March flood includes 5 species of thin filamentous Oscillatoriales belonging to the functional group $\mathrm{S}_{1}$ characteristic of turbid mixed layers, which are new to the system, thus suggesting a potamoplanktonic origin. Also, during the low water period this site was clearly dominated by filamentous central diatoms (particularly Aulacoseira granulata (Ehrenberg) Simonsen), as noted by Zalocar de Domitrovic (2002) for the Paraguay River.

In conclusion, the Riacho Formosa shows a behavior typical of the Chaco-Pampean Plain region, where the hydrologic cycle accounts for most of the variation in physical and chemical features. This effect interacts with the watershed features, thus giving rise to distinct environmental variations along the river course. The floristic composition, structure and abundance of the phytoplankton responds to these variations through two main strategies. One of them, previously observed for similar rives in this area, is the dominance peaks of euryhaline species during low waters, and the other is a high turnover rate, both over space and time, of taxa with distinct ecological preferences.

\section{ACKNOWLEDgeMENTS}

This research was part of the project "Línea de base extendida sobre ecosistemas acuáticos y de humedales - NPU Formosa", directed by M. Sc. Priscilla Minotti, who performed the sampling campaigns together with Lic. María Florencia González. All samples were accessed to by permission of the Ministerio de la Producción y Ambiente (accesion numbers 004770, 005781, 004957, and 004959). The authors are also much indebted to Dr. Yolanda Zalocar de Domitrovic, whom so generously shared with us all of her publications.

\section{Biblography}

CARTER, G. S. \& L. C. BEADLE. 1930. The fauna of the swamps of the Paraguayan Chaco in relation to its environment. I. Physico-chemical nature of the environment. Zool.J. Linn. Soc. 37: 205-258.

CUCCHI, R. J. 1973. Aspectos geomorfológicos de la llanura formoseña. Los ríos sin proporción y su significado climático. Rev. Asoc. Geol. Argent. 28: $156-164$.

DEVERCELLI, M., Y. ZALOCAR DE DOMITROVIC, M. E. FORASTIER \& N. MEICHTRY DE ZABURLIN. 2014. Phytoplankton of the Paraná River Basin. In: TELL, G., I. IZAGUIRRE \& I. O'FARRELL (Eds.), Freshwater phytoplankton of Argentina, pp 39-65. Schweizerbart Science Publishers, Stuttgart.

GARCIA, L. A. \& R. SALINAS. 2014. Estudio de la calidad fisicoquímica y bacteriológica del agua del riacho formosa [online]. Disponible en https:// www.ina.gob.ar/legacy/ifrh-2014/Eje2/2.31.pdf [Acceso: 3 de abril de 2018].

MAGURRAN, A. E. 2004. Measuring biological diversity. Blackwell Science, Oxford.

MINOTTI, P. G. 2016. The Paraná-Paraguay Fluvial Corridor, Argentina. In: FINLAYSON, C. M, C. PRENTICE, \& R. MILTON (Eds.), The Wetland Book: Distribution, Description and Conservation, pp 1-12. Springer Netherlands, Netherlands.

MINOTTI, P., C. RAMONELL \& P. KANDUS. 2013. Regionalización. In: BENZAQUEN, L., D. BLANCO, R. BO, P. KANDUS, G. LINGUA, P. MINOTTI, R. QUINTANA, S. SVERLIJ \& L. VIDAL (Eds.), Inventario de los humedales de Argentina: Sistemas de paisajes de humedales del corredor fluvial Paraná Paraguay, pp 35-90. Secretaría de Ambiente y Desarrollo Sustentable de la Nación, Buenos Aires. 


\section{G. Mataloni et al. - Hydrology and phytoplankton of Riacho Formosa}

REYNOLDS, C. S., V. HUSZAR, C. KRUK, L. NASELLI-FLORES \& S. MELO. 2002. Towards a functional classification of the freshwater phytoplankton. J. Plankton Res. 24: 417-428.

TELL, G. 2014. Phytoplankton diversity. In: TELL, G., I. IZAGUIRRE \& I. O'FARRELL (Eds.), Freshwater phytoplankton of Argentina, pp 5-20. Schweizerbart Science Publishers, Stuttgart.

TELL, G., I. IZAGUIRRE \& I. O'FARRELL. 2014. Introduction. In: TELL, G., I. IZAGUIRRE \& I. O'FARRELL (Eds.), Freshwater phytoplankton of Argentina, pp 1-4. Schweizerbart Science Publishers, Stuttgart.

TER BRAAK, C. J. F. \& P. SMILAUER. 1998.CANOCO reference manual and user's guide to Canoco for Windows: software for canonical community ordination (version 4). Centre for Biometry, Wageningen.

UTERMÖHL, H. 1958. Zur Vervollkommnung der quantitative Phytoplankton-Methodik. Mitt. Int. Ver. Limnol. 9: 1-18.

VENRICK, E. L. 1978. How many cells to count? In: SOURNIA A. (Ed.), Phytoplankton manual, pp. 167-180.Unesco. París.

ZALOCAR DE DOMITROVIC, Y. 2002. Structure and variation of the Paraguay River phytoplankton in two periods of its hydrological cycle. Hydrobiologia, 2002: 177-196.

ZALOCAR DE DOMITROVIC, Y., C. A. BONETTO \& H. G. LANCELLE. 1982. Algunos aspectos limnológicos de la laguna Herradura (Formosa, Argentina). Ecosur 9: 171-188.
ZALOCAR DE DOMITROVIC, Y., M. DEVERCELLI \& M. E. FORASTIER. 2014a. Phytoplankton of the Paraguay and Bermejo rivers. In: TELL, G., I. IZAGUIRRE \& I. O'FARRELL (Eds.), Freshwater phytoplankton of Argentina, pp 67-80. Schweizerbart Science Publishers, Stuttgart.

ZALOCAR DE DOMITROVIC Y., M. DEVERCELLI \& M. E. FORASTIER. 2014b. Phytoplankton of the Chaco-Pampean Plain. In: TELL, G., I. IZAGUIRRE \& I. O'FARRELL (Eds.), Freshwater phytoplankton of Argentina, pp 81-98. Schweizerbart Science Publishers, Stuttgart.

ZALOCAR DE DOMITROVIC, Y. \& M. E. FORASTIER. 2008. Biodiversidad algal del Nordeste Argentino In: BASTERRA, N. I. \& J. J. NEIFF (Eds.), Manual de Biodiversidad de Chaco, Corrientes y Formosa., pp 31-56. EUDENE, Corrientes.

ZALOCAR DE DOMITROVIC, Y., E. R. VALLEJOS \& H. N. PIZARRO. 1986. Aspectos ecológicos de la ficoflora de ambientes acuáticos del Chaco Oriental (Argentina). Ambiente Subtropical 1: 92-111.

Recibido el 25 de octubre de 2017, aceptado el 5 de junio de 2018. Editora: Eugenia Alicia Sar. 
